Stephen Puryear, "Consent by Residence: A Defense"

European Journal of Political Theory (0:0) pp. xx-xx. Copyright (C) 2019

DOI: https://doi.org/10.1177/1474885119833009

\title{
Consent by Residence: A Defense
}

\author{
Stephen Puryear \\ North Carolina State University
}

\begin{abstract}
The traditional view according to which we adults tacitly consent to a state's lawful actions just by living within its borders - the residence theory - is now widely rejected by political philosophers. According to the critics, this theory fails because consent must be (i) intentional, (ii) informed, and (iii) voluntary, whereas one's continued residence within a state is typically none of these things. Few people intend to remain within the state in which they find themselves, and few realize that by remaining they are consenting to the state's lawful actions. Moreover, the various obstacles standing in the way of us leaving the state render our remaining involuntary. Thus, the critics conclude, few if any people can be considered to have consented through their residence. I argue that these objections fail and that the residence theory remains a viable option, at least for those who are not committed incompatibilists.
\end{abstract}

\section{Introduction}

An important strand of social contract theory says that we adults tacitly consent to a state's lawful actions just by residing within its borders. Intuitively, the idea is that if we did not agree with these actions, we would have picked up and left, so that those of us who remain may be taken to have consented to them, even though we may never have bothered to make that consent explicit. For convenience, I will call this the residence theory.

The main idea behind this theory goes back at least to Plato (Crito, 51c-53a) and gets picked up much later by early modern social contract theorists such as Locke (1689: §119) and Rousseau (1762: 4.2). Recently it has been defended in one form or another by a few philosophers, including Beran (1977, 1987), Boxill (1993), Otsuka (2003: 89-113), and Davis (2017). But for the most part it has fallen on hard times. Due primarily to the criticisms of John Simmons (1979: 57-100; 1993), theories of political authority based on actual consent, including the residence theory, have almost universally been abandoned by political philosophers. As Klosko (2005: 122) notes: “In discussions of political obligation, it is now generally 
recognized that a workable theory cannot be based on consent. Adequate numbers of people have not consented to their governments, either expressly or tacitly." ${ }^{1}$

Consent theorists generally agree that in order for an agent $S^{\prime} S \varphi$-ing to effect consent, at least three conditions must be met:

1. S's $\varphi$-ing must be voluntary.

2. S must know that by $\varphi$-ing she consents to the actions of some authority; that is, she must know both that she consents and, at some level of generality, to what she is consenting.

3. In $\varphi$-ing, $S$ must intend to consent (or to communicate consent) to those actions.

We may call these, respectively, the liberty condition, the knowledge condition, and the intention condition.

Given these constraints, my continued residence can effect consent only if (i) I remain within the state voluntarily, (ii) I know that I am thereby consenting to certain actions of the state, and (iii) I intend thereby to consent or to communicate consent to these actions. According to the critics, however, all three conditions raise difficulties for the residence theory. For in the first place, most citizens who remain in the country in which they were raised neither knew that they were thereby consenting to the government's actions, nor intended thereby to consent. Nor did they intend thereby to communicate their consent. In most cases, a person's continued residence meets neither the knowledge nor the intention conditions. Furthermore, and perhaps most importantly, the critics maintain that those who remain in a state rarely do so voluntarily because various obstacles make it difficult if not impossible for them to leave, and insofar as they are unable to do otherwise, their remaining in the state is not free or voluntary. Hence, in most cases, a person's continued residence fails to satisfy the liberty condition as well. (I call this the liberty objection.)

${ }^{1}$ Discussions of our normative relations with the state often focus on the issue of political obligation, that is, properly speaking, our duty to obey the law, or more broadly, what we owe to the state. On my view, such obligations always arise from an act of promising, whereas the act of consenting grants to another some authority and thus, in the political case, concerns what the state is entitled to do with respect to us. Although this essay focuses nominally on consent and political authority, I hold that (subject to the qualifications issued in $\$ \S 3-4$ below) our continued residence within the bounds of a state constitutes both a consenting and a promising act, so that it underwrites both the state's authority over us and our obligation to obey the laws. 
These objections are typically regarded as fairly quick and decisive refutations of the residence theory. Critics usually state them briefly, discard the theory, and move on. Quick though they may be, however, it seems to me that they are anything but decisive. In fact, I think they fail to cast any serious doubt on the residence theory. In what follows, I will attempt to show why by arguing for the following claims, taking the three conditions and the corresponding objections in reverse order.

First, there is no general requirement of intention for consent: legitimate, authority-granting consent requires neither that one intend to consent nor that one intend to communicate consent, and in cases of passive consent, whereby one consents through some form of inaction, one need not even intend the consenting inaction $(\S 2)$.

Second, regarding knowledge, consent requires not that the agent actually know that and to what she is consenting, but only that there be a reasonable expectation that she would know such things - an expectation that does generally obtain in the case of residence within a state (§3).

Third, so long as we are willing to grant that free or voluntary action is compatible with the inability to do otherwise, as most philosophers believe, then we have good reason to believe that continued residence does widely satisfy the liberty condition, at least in the case of liberal democracies $(\S 4)$.

In view of these points, I conclude that none of these objections to the residence theory succeed. At least for those who are not committed incompatibilists, that theory remains a viable option for explaining the broad (though not universal) political authority of many contemporary states.

\section{The Intention Condition}

Many critics of the residence theory maintain that consent requires an element of intention. Typically the idea is that consent presupposes an intention to consent. ${ }^{2}$ They then object that few if any people who remain within the boundaries of a state intend thereby to consent to anything, least of all the state's actions. Hence, it follows that continued residence typically fails to satisfy the intention condition, and thus typically fails to be a consenting act, in which case the residence theory fails as a theory of the general consent of a people to the actions of a state.

2 See, e.g., Flathman (1972: 220); Simmons (1979: 77); Simmons (1993: 226-28); Lefkowitz (2006: 579); Horton (2010: 29); Kleinig (2010: 17-20); Simmons (2010: 306, 317-18). 
In reality, however, consent does not always require the intention to consent. ${ }^{3}$ This may be illustrated with an example. On a recent visit to Barbados, I encountered a prominent sign hanging outside the port terminal, which read: "ENTERING THIS FACILITY IS DEEMED VALID CONSENT TO SCREENING OR INSPECTION." As I approached the terminal, I saw and understood the sign's meaning; I then proceeded to enter the terminal voluntarily. So both the knowledge and liberty conditions were satisfied. Furthermore, it seems clear that in knowingly and voluntarily entering the terminal, I did indeed consent to being screened or inspected. But at no point did I intend to consent to such actions. To be sure, I did intend to enter the country of Barbados; and for that reason I also intended to enter the terminal. These were my aims or goals. But I did not intend to consent to being screened or inspected, even though I knew that by entering the terminal, I would be consenting to such actions. To intend something in this sense is to have it as an aim or goal of one's action. But at no point was it one of my aims or goals to be screened or inspected. Rather, I intended only to enter the terminal, and thereby to gain access to the streets of Bridgetown. Nonetheless, because I entered the terminal voluntarily, and knew that doing so would be considered a consenting act, it seems clear that I thereby consented to being searched by the authorities. Hence, consenting does not require the intention to consent.

Suppose the authorities had attempted to search me. Had the sign been missing, and had there been no way for me to know that entering the terminal was considered a consenting act, I would have had a valid complaint: I did not know, and could not have been expected to know, that entering the terminal was considered a consenting act. In such a case, the knowledge condition would not have been satisfied, and so there would have been no consent. Similarly, had I been forced to enter the terminal against my will, the liberty condition would not have been satisfied, and clearly there would have been no consent. But suppose that I knowingly and voluntarily entered the terminal, but objected that the authorities had no right to search me because at no point did I form the intention to consent to such a search. It seems clear that such an objection would fall flat, and rightly so. Whether I intended to consent is beside the point. What matters is only that I voluntarily performed what I knew would be a consenting act.

In his most careful treatment of this issue, Simmons (1993: 226-30) reiterates the requirement that consent must be given intentionally, but then issues a significant qualification: "It is hard to deny that there might be some cases where it seems possible to give binding consent without intending to do so or being

${ }^{3}$ For a related but different response to this objection, see Boxill (1993: 82-88). 
aware of the consequences of our act" (Simmons, 1993: 229). He gives the example of man who orders food in a restaurant, but due to ignorance or confusion about how restaurants work, fails to realize that he is expected to pay for the food. Simmons grants that if the man's ignorance or confusion were excusable, then his ordering would not have bound him to pay for the food. But he adds that if the man's ignorance or confusion were inexcusable-if he should have known that ordering food in a restaurant is a binding act-then the man would have in fact committed himself to paying, even though he did not intend to make any such commitment. Thus, even Simmons admits that binding consent can occur in the absence of any intention to consent.

I agree. The example of the willfully or at least inexcusably ignorant man who orders food in a restaurant nicely illustrates the possibility of consenting (or obligating oneself) in the absence of any intention to consent. But it should be noted that this is not the only kind of case in which binding (or authority-granting) consent does not require the intention to consent. As my Barbados example shows, this can happen even when the missing intent is not due to some (inexcusable) ignorance or confusion. I know full well that entering the terminal is understood to be a consenting act, and that by performing this act I succeed in consenting. Yet I lack the intention to consent. Even in cases in which there is no inexcusable ignorance or confusion, then, the intention condition is not a necessary condition for consent.

Another kind of case that buttresses my point is that of the insincere consenter. Suppose the police, finding me at the scene of a crime, ask me whether I would consent to a search of my home. In the hopes of not raising further suspicion, I say that I do indeed consent to such a search. But even though I say this, I do not in fact intend to consent to any such search; rather, I intend only to feign consent. In fact, I have every intention of turning the police away if they appear at my house. My expression of consent is insincere. But notice that whether I intend to consent is irrelevant to whether I actually do consent. What matters is that I knowingly and willingly perform an action of a kind that serves to effect consent in that context. My action is genuinely consenting, even though I do not intend thereby to consent. Indeed, I may even have intended not to consent. But that is beside the point. In knowingly and willingly signaling my consent, I thereby succeed in consenting, even if that was not my real intent.

The case of the insincere consenter presents a problem for proponents of the intention condition because it suggests that a person who merely feigns consent, and thus does not intend to consent, nonetheless succeeds in consenting. In a recent updating of his view, Simmons (2010:317) appears to address this problem 
by recasting the intention condition. He notes that "Just as an insincere promise may nonetheless bind us to perform as promised, so consent that intentionally and successfully communicates our undertaking of obligation, even in the absence of any intention on our part to honor our consent, may (and typically does) still bind us." Thus, he suggests that what consent requires is not so much the intention to consent as the intention to communicate consent: "we must intend for our actions to communicate (and must succeed in communicating) to others that we thereby undertake new obligations with respect to them and/or convey to them new rights." 4 On this view, there is no difficulty in explaining how the insincere consenter could nonetheless consent without intending to do so: for she still intends to communicate consent, as in the example of the previous paragraph, in which I misrepresent my wishes to the police in order not to raise suspicion. Perhaps what consent really requires with respect to intent, then, is the intention to communicate consent.

The problem with this move is that consent does not require the intent to communicate consent either. Consider again the Barbados example. I understand that by entering the terminal, I consent to being searched. But my intention in entering the terminal is not to communicate that consent, any more than it was to consent. To the contrary, my intention in entering the terminal is to get to the other side, to access the city, and so forth. I understand that by entering the terminal I am signaling to the authorities my willingness to be searched; but that is not my intention. It is not my aim or goal to signal this to the authorities, even though I know that I am doing so. Thus, consent does not require that one intend to communicate one's consent. As long as the consenting act is performed voluntarily, and in a sufficiently informed way, then the agent has in fact consented.

I have argued that consent requires neither the intention to consent nor the intention to communicate consent. So far as this is correct, the fact that citizens who remain within the boundaries of a state typically do not intend thereby either to consent or to communicate consent does not prevent their continued residence from effecting consent. However, there remains a further concern. For one might still hold that consent must be intentional in the minimal sense that one must intend to perform the consenting act. This is different from saying that one must intend to consent or to communicate consent. The thought is merely that one must

4 Emphasis in original. Lefkowitz (2006: 579) also requires the intent to communicate consent, but he appears to require this in addition to the intention to consent, not instead of it. 
intend to perform whatever action happens to be the consenting act. In the Barbados example, the idea would be that I must intend to enter the terminal in order for my doing so to effect consent. So understood, the intention condition might still present a problem for the residence theory; for it might be supposed that few people who remain within the state in which they were raised ever intend to remain there. Perhaps most such people do not give the matter of leaving or staying any serious thought, but merely remain as a matter of inertia, without consciously intending to do so. If that were true, then continued residence might still typically fail to satisfy the intention condition for consent.

It is far from obvious that most adults living within a state have not at some point intended to be or to remain there. But even if that is the case, this lack of intention is not a problem for the residence theory. For the requirement that one intend to perform the consenting act arguably applies only in cases of active consent-consent given through action-and not in cases of passive consent, that is, consent given through inaction. To see why, consider a variation on an example given by Michael Huemer (2013: 23). Suppose I throw a party at my house and you are in attendance. As the night wears on, I announce that those in attendance may stay as late as they like, but that anyone who stays past ten o'clock consents to me charging their credit card to help cover cleaning expenses. You hear this announcement and process it, but being engrossed in conversation, give the matter no further thought and soon lose track of time. 10:30 rolls around, and I ask for your credit card number. Recalling my announcement, you protest that even though you knew this condition was in force, you did not intend to stay past ten, indeed even intended to leave before ten, and thus did not really consent to me charging your card. Few will deny, I think, that under such circumstances, the fact that you did not intend to perform the consenting act-did not intend to stay past ten -in no way undercuts my right to charge your card. It is really quite beside the point whether you formed the intention to stay past ten or not. What matters is only that you willingly and (in a sense to be clarified below) knowingly stayed past ten: no one forced you to stay or stopped you from leaving, and you knew this condition was in force, even though you temporarily lost sight of this fact due to inattention. In other words, what matters is only that the knowledge and liberty conditions were satisfied.

In cases of active consent, whether express or tacit, it is surely true that one must intend to perform the consenting act: I must intend to enter the terminal, to 
raise my hand, to sign on the dotted line, and so forth. ${ }^{5}$ In cases of passive consent, however, the party example suggests that one need not intend to refrain from acting in order for one's inaction to effect consent. And this is good news for the residence theory; for remaining within a state is most plausibly viewed as passive rather than active, as a form of inaction rather than action. Hence, it follows that one need not intend to remain within a state in order for one's remaining to effect consent. All that is required is that one consent knowingly and with liberty.

If these points are right, then intention is not after all required for consent: one need not intend either to consent or to communicate consent, and in cases of passive consent, such as continued residence, one need not even intend to forbear from acting. As far as intention is concerned, then, there is no difficulty in supposing that all rational, adult residents within a state have consented to the state's authority through their residence.

\section{The Knowledge Condition}

Many critics also contend that the residence theory fails because a person's continued residence rarely meets the knowledge condition. As I have formulated that condition, it says that an agent $S^{\prime}$ s $\varphi$-ing can effect consent only if $S$ knows that in $\varphi$-ing she consents to certain actions on the part of some other agent, in this case the state. That is, $\mathrm{S}$ must know both that she consents and, at some level of generality, to what she is consenting. The problem this raises for the residence theory is that very few people who remain in a country once reaching the age of consent know or realize that they are thereby consenting to the authority of the government. And since the residence theory is supposed to explain how the state comes to have authority over most if not all of its citizens, this is a serious problem.

I do not know whether most people realize or know that by remaining within the boundaries of the state, they are consenting to the state's authority. Perhaps most, perhaps even the vast majority, do not. But in any case I will not challenge this point. I want to pursue a different line of reply.

Some theorists have observed that what consent requires with respect to knowledge, properly speaking, is not that one knows that one is consenting, but

\footnotetext{
${ }^{5}$ The defining mark of tacit consent is not that it is passive, as some have suggested (Plamenatz, 1968: 8; Simmons, 1979: 80; Horton, 2010: 29), but that it is given through actions (or inactions) that do not have the conventionally established purpose of effecting consent, but which nonetheless serve that purpose in a given social context (cf. Simmons, 2010: 315-16).
} 
that one not be blamelessly ignorant that one is consenting. That is, it must be that the person knows, or least should have known-could reasonably be expected to know-that she was consenting through her action. ${ }^{6}$ In order to refute the residence theory, then, it is not enough to show that most citizens do not realize that their continued residence is a consenting act. What must be shown is that they could not reasonably have been expected to realize this.

In his defense of the residence theory, Beran (1977: 270) exploits this very point. He claims that "Adults in contemporary states with universal education" do in fact know each of the following:

1. In remaining within the territory of a state when one comes of age one accepts full membership in it.

2. In accepting membership in a rule-governed association (in the absence of coercion, deception, etc.) one puts oneself under an obligation to obey its rules.

3. The state is a rule-governed association.

He then notes that these three claims jointly entail that

4. In remaining within the territory of a state when one comes of age (in the absence of coercion, deception, etc.) one puts oneself under an obligation to obey its rules.

Finally, he claims that even though many citizens may not make the inference from (1)-(3) to (4), and thus may not know (4), that does not prevent consent from coming off, because their ignorance of (4) may well be negligent: "It may well be negligent, since people should consider what moral significance there is in their new status and their new rights" (270). In other words, they should make the inference from (1)-(3) to (4).

Simmons (1993: 230-32) criticizes this reply by questioning whether ordinary citizens really do know (1)-(3). He notes that "Beran merely asserts that ordinary persons understand these matters" and claims that "it would seem peculiar (or even unreasonable) for ordinary persons to hold the views ascribed to them by Beran" (Simmons, 1993: 231). For they do not act as if they believe that coming of age marks a sharp break in the course of their political lives, a break at which they attain full membership in a rule-governed association. Consequently, Simmons concludes, "the claim that the ignorance of such persons is 'negligent' seems ridiculous."

${ }^{6}$ For helpful discussion of the details here, though in the context of moral responsibility rather than consent, see Sher (2009), especially Chapter 5 and beyond. 
For my part, I fail to see how citizens of the sort Beran has in mind could fail to grasp claims (2) and (3). With few exceptions, everyone knows, in effect, that the state is a rule-governed association, and it is widely understood that accepting membership in such an association entails an obligation to obey its rules. With respect to (1), however, Simmons has a point: one may reasonably doubt whether ordinary citizens, even ones with a "universal education", know or believe that a person accepts full membership in the state by remaining within its boundaries as an adult. As it stands, therefore, Beran's reply falls short.

Beran is nonetheless on the right track. Given that what consent requires is not knowledge but a reasonable expectation of knowledge, the salient question is not whether most ordinary adults actually know that by remaining within the state, they are consenting to the state's authority. The salient question is whether they should know this, that is, whether ignorance of this point is excusable. I want to suggest that it is not.

Consider that most educated adults well understand that when they travel to another country or even just to another jurisdiction, they are submitting to the authority of the relevant government. They understand that they are subject to the laws of that jurisdiction, even if they do not know the precise content of those laws. They understand that if they are caught breaking a law, they cannot expect to get off by pleading ignorance or by noting that they are only visitors. But if it is true that these points are widely grasped by educated adults, then it should also be widely understood that by freely remaining in their home country (or jurisdiction), they are likewise consenting to the authority of that government. It is a small step indeed from the claim "In willingly entering another jurisdiction, I thereby consent to its authority" to the claim "By willingly remaining in this jurisdiction, I thereby consent to its authority." Because remaining is passive, whereas entering is active, many people may fail to make this inference, and the latter claim may never distinctly occur to them. But it would be irrational to believe the former and not also believe the latter. Hence, most citizens could reasonably be expected to know that their continued residence constitutes consent. In Beran's terms, most citizens could be expected to know (1), and given that they also know (2) and (3), they could reasonably be expected to know (4). Any rational, well-educated citizen who fails to know this is therefore inexcusably ignorant.

Properly construed, then, the knowledge condition can be considered to be widely satisfied by rational adults who continue to reside within the borders of a state. Even though they may not actually realize that their remaining is a consenting act-the thought may have never occurred to them - the fact remains 
that they should have realized this, could reasonably be expected to realize this. And that is all that consent requires with respect to knowledge.

Because it generally satisfies the knowledge condition, the case of continued residence also provides what Simmons (2010: 316) calls a "clear choice situation" (cf. Simmons, 1993; 2001: 166-171, 177-178). According to Simmons, a case of express consent "creates its own context by positively invoking standing linguistic (or other) conventions for giving consent." But in cases of tacit consent, where consent is given by a kind of action or inaction that lacks this conventionally established context-creating quality, that context must be provided. In my Barbados example, this context is provided by the sign: merely walking into a building, we might think, even a port terminal, does not normally constitute a consenting act, and so the sign is necessary in order to establish the significance of entering the building in that context. This is what Simmons means by a clear choice situation: it must be clear to the agent that a certain action (or inaction) will have such-and-such implications in this situation. Now in the case of continued residence, it might be thought that there is no clear choice situation, because there is nothing analogous to the sign which informs people that by remaining, they are consenting to the state's actions, and that they can refrain from consenting only by leaving. But if I am right that most rational adults could reasonably be expected to know these facts even in the absence of some explicit statement of them - even in the absence of something analogous to the sign - then we do have a clear choice situation. It is clear, or at least should be clear, that their continued residence expresses and thus effects consent, that they could refrain from consenting only by leaving, and so forth.

\section{The Liberty Condition}

Having dealt with the intention and knowledge conditions, I now come to what has traditionally been viewed as the Achilles heel of the residence theory: namely, that one's continued residence typically fails to satisfy the requirement that a consenting act be voluntary or free. This objection, the liberty objection, was first and most famously articulated by Hume (1748: 283):

Should it be said, that, by living under the dominion of a prince which one might leave, every individual has given a tacit consent to his authority, and promised him obedience; it may be answered, that such an implied consent can only have place where a man imagines that the matter depends on his choice. [...] Can we seriously say, that a poor peasant or artisan has a free choice to leave his country, when he knows no foreign language or 
manners, and lives, from day to day, by the small wages which he acquires? We may as well assert that a man, by remaining in a vessel, freely consents to the dominion of the master; though he was carried on board while asleep, and must leap into the ocean and perish, the moment he leaves her.

The key word here is "choice". According to Hume, there can be an implied or tacit consent to the state's authority only if the consenting action or inaction -in this case, one's continued residence-is a matter of choice, that is, free choice. But most of us, at least, do not really have a choice about whether to stay or leave the country, because of the considerable barriers to exit - financial, cultural, familial, and so forth. For most of us, then, our continued residence cannot be construed as a form of consent, because it is not free: we have no choice but to stay. ${ }^{7}$

This objection has been echoed many times over the years, and continues to be urged today by critics of the residence theory. Simmons (Wellman and Simmons, 2005: 118) is typical:

Mere continued residence (Locke's famous suggestion) or nonresistance, for instance, while widely practiced, are in fact remarkably bad candidates for acts of consent to obey. For many citizens there are few acceptable options to remaining in their states and obeying (most) law, and for most persons active resistance to the state is in effect impossible. And for none of us is there any option [i.e., alternative] to living in some state or other, all of which make (at least) the same core demands on us. These facts raise serious doubts about the voluntariness of any widely performed acts that might be alleged to be binding acts of political consent. And in the absence of an adequate level of voluntariness, such acts simply cannot be counted as grounding moral duties to obey the law. ${ }^{8}$

\footnotetext{
${ }^{7}$ Hume can also be read as making the point that continued residence often fails to satisfy the knowledge condition. For he says that "such an implied consent can have place only where the man imagines that the matter depends on his choice" (emphasis mine), and it would seem to be an implication of the remainder of the passage that the poor peasant or artisan cannot be supposed to imagine any such thing.

${ }^{8}$ For other recent statements of this objection, see, e.g., Woozley (1979: 106-8); Simmons (1979: 98-99; 1993: 233-48); Higgins (2004: 105-9); Klosko (2005: 125); Lefkowitz (2006: 580); Wolff (2006: 42-43); Horton (2010: 34); Knowles (2010: 109 10); Huemer (2013: 25-35).
} 
The point here is the same basic one raised by Hume, though Simmons speaks in terms of consent being voluntary rather than free. ${ }^{9}$ The bottom line is that for most us, our continued residence is not voluntary because we are not able to leave the country in which we reside. And even if we could, we probably could not escape the laws of some country or other, all of which make "the same core demands on us". Hence, our continued residence is not voluntary. And as consent must be voluntary, our continued residence cannot be supposed to effect consent. ${ }^{10}$

Hume and Simmons appear to be arguing that our remaining within the bounds of a state is not free or voluntary simply because we have no choice but to stay. If that were the objection, though, it would at the very least stand in need of considerable elaboration, since it would rest on the notoriously controversial and widely rejected principle that free (or voluntary) action requires the ability to do otherwise. In one of his more recent discussions, however, Simmons (2010) offers a more nuanced and promising version of this objection. After quoting Hume, he makes the usual point that our remaining cannot be voluntary if leaving is not a viable option:

Hume suggests that for many (especially the poor) emigration is not really a viable option, so that the "choice" being presented constitutes no genuine choice at all. This indicates that the voluntariness condition for binding consent cannot be satisfied for the case of continued residence as an act of political consent. (Simmons, 2010: 320-321)

But it's clear that the usual point is not quite what Simmons has in mind. For just a few pages earlier, he grants that one's remaining can be free even if one cannot leave:

While we may, of course, freely consent to an arrangement even where we have no viable options to doing so (just as a person whose exits have been secretly blocked may nonetheless freely choose to remain in her home for the evening), "consent" given only because of the absence of options especially where others have removed those options precisely in order to compel consent-typically does not bind us. (Simmons, 2010: 318, emphasis in original)

9 Some philosophers, e.g., Locke (1690: 2.21.8), distinguish between the free and the voluntary. In this context, however, we can take the two concepts to be equivalent.

${ }^{10}$ For other responses to this objection, see Beran (1977: 166-68; 1993: 493-98; 1987: 95-108); Boxill (1993: 88-92); Otsuka (2003: 105-7); Gilbert (2006: 75-82, 215-37). 
As this passage makes clear, Simmons' point is not that our remaining fails to be voluntary merely because we have no alternative; his claim is rather that our remaining fails to be voluntary if we remain only because we have no alternative, especially if these alternatives have been removed by others in order to force us to remain. Furthermore, in the slightly later passage where he states the liberty objection, he goes on to say, immediately following the words quoted above:

Even if consent is not exactly coerced by the state in requiring a choice between consent or emigration, it seems nonetheless true that in doing so the state counts as exploiting the vulnerability of those who find themselves within its claimed territories and thus rendering their choice insufficiently voluntary to count as binding. (2010: 321; cf. Simmons, 1993: 240-241)

This adds the idea that our remaining fails to be voluntary not just because of the absence of options, but because the absence of options gives rise to a vulnerability that the state exploits in forcing us to choose between consent or emigration. So even if we are not coerced, we are exploited, and that is enough to render our residence insufficiently voluntary.

So what about this more nuanced version of the liberty objection? First of all, Simmons is quite right that if we remain within a state only because we have no alternatives, then our remaining is not voluntary. For our remaining is voluntary only if we want to remain, and if we want to remain, then we are not doing so only because we cannot leave. Put otherwise, if we remain only because we cannot leave, then it follows that we do not want to remain: we want to leave but cannot. In such a case, we remain against our will, and our remaining is thus involuntary. ${ }^{11}$

Consider Locke's well-known example, akin to Simmons' example of the person whose exits have been secretly blocked, of the man who awakes to find himself in a locked room, accompanied by someone he "longs to see and speak with" (Locke, 1690: 2.21.10). ${ }^{12}$ Since the man is "glad to find himself in so desirable Company" and "prefers his stay to going away," Locke concludes that the man stays willingly, that is, voluntarily, even though he is unable to leave. (Those who prefer Frankfurt cases may imagine that the door is unlocked, but that an

${ }^{11}$ Cf. Rousseau (1762: 4.2, n1): “This [i.e., that residence implies consent] should always be understood of a free state; for else family, goods, lack of refuge, necessity, [or] violence can keep an inhabitant in a country in spite of himself [malgré lui]; and then his merely staying does not imply his consent to the contract or to the violation of the contract" (emphasis mine).

${ }^{12}$ For a similar appropriation of Locke's example, see Otsuka (2003: 106-7). 
intervener stands ready to lock it if the man attempts to leave.) What this appears to show is that the man's staying is voluntary just in case the man wants to stay. More generally, it appears to show that one acts voluntarily just in case one does what one wants. As long as the man prefers staying over leaving, his staying is voluntary; the fact that he cannot do otherwise is beside the point. But were he to change his mind and decide to leave, then his remaining would no longer be voluntary. In that case, and only in that case, would he be remaining only because he has no options.

In order for this version of the liberty objection to cut any ice, it would need to be the case that most people who remain within a state do so only because they have no options..$^{13}$ But is this really the case? No, it isn't, at least not within most liberal democracies. Consider as a representative example the United States. Is it true that most people who live in this country do so only (or even primarily) because they have no readily accessible alternatives? Surely not. True, there are some people living here who never wanted to be here, and who would prefer to leave and would leave if given the opportunity, but who for one reason or another are unable to do so. I readily grant that such people do not consent through their residence, though of course they may have consented in some other way, such as by taking an oath. But such people would seem to represent a very small minority of the total population, probably less than ten percent. It would appear that the vast majority of people living in this country genuinely want to be here, and remain here at least in part, if not in whole, because they want to be here, and not just because they cannot leave. ${ }^{14}$ Most Americans, I suspect, would decline to emigrate to another country or even to some libertarian paradise in another part of the world, even if the respective governments made this a ready possibility, because most of them genuinely want to be here, whether out of nationalistic loyalty, a deep connection to place or people or culture, or even just inertia. To borrow a phrase from Otsuka (2003: 107), they find being here "positively

${ }^{13}$ Cf. Beran (1983: 494-495): "[I]t is not a criterion of the success of a theory of political authority that it assert principles according to which a government stands in an authority relation to every adult within its borders. Consent theory is tenable as long as it is possible to create states in which the vast majority of residents can stand in a political authority relation to the state, which is based on their consent." ${ }^{14}$ Note that I am not suggesting that most residents willingly accept the authority of the state, only that they willingly remain within the state. The issue here is not their attitude toward the state, but whether their remaining is voluntary. Cf. Simmons (1993: 246). 
attractive in absolute terms" and not just attractive relative to one or more even worse alternatives. They are thus not like the person who takes refuge in a tree in order to escape the raging flood waters below (Otsuka 2003: 106). Such a person admittedly chooses to climb the tree not because she finds that choice attractive in its own right, but because she considers the alternative even worse. Her decision to scale the tree is made under duress, and for that reason is insufficiently voluntary to qualify as a consenting act. In contrast, most citizens of a liberal democracy do not remain within the state under duress; for the high cost of the alternative is irrelevant to their desire to remain. They find the idea of remaining attractive in its own right, not just relative to an even worse alternative: they are not here in spite of themselves, as Rousseau (1762: 4.2,n1) puts it, but in accord with themselves. The fact that they lack a good alternative cannot therefore be a good reason for considering their residence involuntary.

Simmons' other suggestion is that our remaining often fails to be voluntary because in treating residence as a consenting act in the absence of viable options, the state exploits our vulnerability. We may illustrate the situation as follows. Suppose I come across a person in dire straits, and realizing that she has no options for escape, I offer her a way out on the condition that she participate in my criminal enterprise. If she accepts my offer in order to avoid the alternative-death, let us say-we might well think that she did not do so voluntarily - that she had no choice, as we say-and thus that she is not culpable for her criminal activities, because she was the victim of exploitation. Similarly, a state that treats our residence as a consenting act when we have no choice but to be here, the thought goes, exploits our vulnerability and thus renders our residence involuntary.

As to the general principle here, I readily grant that if one person exploits another's lack of options in order to compel or pressure the latter to do something that they would not otherwise do-that they do not want to do, in other wordsthen the situation is exploitative and the latter person cannot be considered to have acted voluntarily. But the key here is that the person is being forced to do something against her will. Consider again the locked room. If the man wants to leave, then it would be fair to say that the one who put him there and locked the door has exploited his vulnerability and that the man's remaining is thus not voluntary. But if the man genuinely wants to be there, if he would have entered the room of his own volition in order to meet his friend, if he would have stayed in the room even if the door were unlocked, then can we really consider the circumstances exploitative? Can we really say that the man stays there involuntarily? I hardly think so, and Simmons himself concedes as much. So whether this point succeeds as an objection to the residence theory depends on 
whether, or rather on the extent to which, the residents within a state genuinely want to be there. And as I have already noted, it seems that the vast majority of residents in liberal democracies such as the United States genuinely want to be there. Their situation is much like that of the man in the locked room, who finds himself put there without his prior consent but nonetheless prefers staying to leaving because of the desirable conditions. Though we might grant that the few who prefer to be elsewhere do not remain voluntarily and are even the victims of an exploitative situation, in the vast majority of cases one's residence can be considered just as voluntary as the man's remaining in the room. The liberty objection thus still falls short.

One further worry remains. I have suggested that one's remaining is voluntary just in case one wants to remain. But suppose that one's wants are the result of some kind of extreme manipulation, such as brainwashing or oppressive conditioning. In such cases, it would seem that a person may still fail to act voluntarily even when she does what she wants. Thus if the man had not only been placed in the locked room but brainwashed into thinking that he wanted to be there, then we would not consider his remaining voluntary, even though he might insist otherwise. Similarly, it might be thought that residence cannot be considered voluntary even if most residents want to be in that state, because their wanting to be there results from some such manipulation, perhaps by the state.

Once again I readily admit the general principle: if a person's desires are the result of this kind of extreme manipulation, then that person is not free even when she does what she wants. But once again I question its relevance. For few if any residents in present-day liberal democracies seem to be the victims of such manipulation, at least with respect to their attitudes toward the state. To be sure, many people are conditioned to be patriotic and nationalistic, and perhaps even to think that their home country is superior to others. As children, we are taught to pledge allegiance to the flag, to sing the national anthem, to revere our founding documents, to celebrate national holidays, and so forth. But this falls well short of the kind of manipulation that robs one of freedom. The characteristic feature of this kind of manipulation, I would suggest, is that it bypasses, short-circuits, or overrides a person's rational faculty, thus leaving the person insufficiently sensitive to relevant reasons. ${ }^{15}$ For instance, if oppressive conditioning left a person insensitive to the oppressiveness of a regime as a reason for fleeing, then that person's remaining could not be considered voluntary, even if she wanted to

${ }^{15}$ For developments of this sort of approach, see Wolf (1990), Fischer and Ravizza (1998), and Fischer (2004). 
remain. But the kind of nationalistic conditioning that we often see in liberal democracies does not go this far; it does not circumvent people's rational faculties in a way that leaves them insufficiently sensitive to relevant reasons. So while this might be a problem for the residence theory as applied to oppressive dictatorships, it is not a problem for the theory as applied to liberal democracies such as the United States.

In view of all this, I conclude that the liberty objection fails. In its basic form, it falls flat because it tacitly assumes a highly controverted principle about freedom and the ability to do otherwise. In its more nuanced forms, it fails because in modern liberal democracies, a person's residence typically fails to satisfy any of the cited freedom-defeating conditions: it is neither forced, nor exploitative, nor manipulated. As long as we grant that voluntary action does not require the ability to do otherwise, then, it seems that the residence theory does succeed in establishing that such democracies have legitimate, consent-based authority over the vast majority of their (adult) denizens by dint of their continued residence. ${ }^{16}$

\section{Conclusion}

Critics of the residence theory typically reject that theory on the ground that a person's remaining within the bounds of a state generally fails to satisfy one or more of the three conditions of consent discussed here, namely, the intention, knowledge, and liberty conditions. Against this, I have argued that there is no general requirement of intention for consent. Consent does not require that one intend either to consent or to communicate consent, and when consent is given passively, as in the case of continued residence, one need not even intend the inaction. Further, I have argued that the knowledge condition requires only that there be a reasonable expectation that one would know that and to what they are consenting, and that this condition, so understood, is widely satisfied: most adult residents of modern, liberal democracies know, or at least could reasonably be expected to know, that in remaining they are consenting to the lawful actions of the government. Finally, I have argued that the liberty condition is also widely satisfied in such democracies, at least if freedom is compatible with the inability

\footnotetext{
${ }^{16}$ Here I part company with those (actual) consent theorists, such as Walzer (1970: 99-119), Beran (1977; 1983; 1987), and Boxill (1993), who hold that current states must be reformed in some way before they can claim to have legitimate, consentbased authority over their residents.
} 
to do otherwise, as many philosophers believe. In short, none of the conditions of consent, properly understood, clearly fails to be satisfied in a wide range of cases.

I have here sought only to defend the residence theory against the most common objections. Perhaps better ones can be produced, but it is hard to see how the usual objections can be considered a success. Despite their popularity, they are far from conclusive or even probably sound. If the critics want to refute the residence theory, they need to do better. As things stand, we have been given no good reason to doubt that a great many residents of liberal democracies have in fact consented to the lawful actions of the state in virtue of their continued residence within its boundaries, apart perhaps from the controversial doctrine that freedom requires the ability to do otherwise. At least for those who reject this doctrine, the residence theory remains a viable option.

\section{References}

Beran H (1977) In defense of the consent theory of political obligation and authority. Ethics 87(3): 260-271.

Beran H (1983) What is the basis of political authority? The Monist 66(4): 487-499.

Beran H (1987) The Consent Theory of Political Obligation. New York: Croom Helm.

Boxill B (1993) On some criticisms of consent theory. Journal of Social Philosophy 24(1): 81-102.

Davis M (2017) Locke, Simmons, and consent: a lawyerly approach. Social Theory and Practice 43(4): 667-690.

Fischer JM (2004) Responsibility and manipulation. The Journal of Ethics 8(2): 145177.

Fischer JM and Ravizza M (1998) Responsibility and Control: A Theory of Moral Responsibility. New York: Cambridge University Press.

Flathman RE (1972) Political Obligation. New York: Atheneum.

Gilbert M (2006) A Theory of Political Obligation. New York: Oxford University Press.

Higgins RCA (2004) The Moral Limits of Law: Obedience, Respect, and Legitimacy. New York: Oxford University Press.

Horton J (2010) Political Obligation. $2^{\text {nd }}$ ed. New York: Palgrave Macmillan.

Huemer M (2013) The Problem of Political Authority: An Examination of the Right to Coerce and the Duty to Obey. New York: Palgrave-Macmillan.

Hume D (1748) Of the original contract. In: Copley S and Edgar A (eds) David Hume: Selected Essays. New York: Oxford World's Classics, 2008, pp. 274-292. 
Kleinig J (2010) The nature of consent. In: Miller FG and Wertheimer A (eds) The Ethics of Consent: Theory and Practice. New York: Oxford University Press, pp. 3-24.

Klosko G (2005) Political Obligations. New York: Oxford University Press.

Knowles D (2010) Political Obligation: A Critical Introduction. New York: Routledge Press.

Lefkowitz D (2006) The duty to obey the law. Philosophy Compass 1(6): 571-598.

Locke J (1689) Second Treatise of Government.

Locke J (1690) An Essay Concerning Human Understanding.

Otsuka M (2003) Libertarianism without Inequality. New York: Oxford University Press.

Rousseau J-J (1762) On the Social Contract.

Sher G (2009) Who Knew? Responsibility without Awareness. New York: Oxford University Press.

Simmons AJ (1979) Moral Principles and Political Obligations. Princeton, NJ: Princeton University Press.

Simmons AJ (1993) On the Edge of Anarchy: Locke, Consent, and the Limits of Society. Princeton, NJ: Princeton University Press.

Simmons AJ (2001) Justification and Legitimacy: Essays on Rights and Obligations. New York: Cambridge University Press.

Simmons AJ (2010) Political obligation and consent. Miller FG and Wertheimer A (eds) The Ethics of Consent: Theory and Practice. New York: Oxford University Press, pp. 305-328.

Walzer M (1970) Obligations: Essays on Disobedience, War, and Citizenship. Cambridge, MA: Harvard University Press.

Wellman CH and Simmons AJ (2005) Is There a Duty to Obey the Law? New York: Cambridge University Press.

Wolf S (1990) Freedom Within Reason. New York: Oxford University Press.

Wolff J (2006) An Introduction to Political Philosophy. New York: Oxford University Press.

Woozley AD (1979) Law and Obedience: The Arguments of Plato's Crito. Chapel Hill: University of North Carolina Press. 